\title{
Anticancer Profiling of Gambogic Acid as a Target Specific RANKL Inhibitor in Osteosarcoma Cell Line
}

\author{
Aykut ÖZGÜR ${ }^{1 *}$, Esra DUMANº
}

\author{
${ }^{1}$ Tokat Gaziosmanpaşa University, Artova Vocational School, Department of Veterinary Medicine, \\ Laboratory and Veterinary Health Program, Tokat, Turkey \\ Geliş / Received: 27/04/2021, Kabul / Accepted: 08/06/2021
}

\begin{abstract}
Osteosarcoma is a common cancer type among the youth population and usually develops in growing bones. Approximately twenty percent of osteosarcoma cases show tendency to metastases and patients with osteosarcoma have a low survival rate after treatment. RANK/RANKL/OPG key regulator triad of bone remodeling play critical roles in tumourigenesis of osteosarcoma. Anti-proliferative activity of the gambogic acid was determined in Saos-2 cell line by XTT assay. To understand the anticancer activities of the gambogic acid, molecular docking calculations were also performed with RANK-RANKL complex. The expression levels of the RANKL and OPG was measured at gene and protein level with RT-PCR and ELISA assays. Its potential anti-invasive property in-vitro against osteosarcoma cells was evaluated using wound healing assay. Experimental assays indicated that gambogic acid suppressed cell proliferation, cell migration, and decreased protein expression ratio of RANKL/OPG in Saos-2 cells. Gambogic acid binds to RANK-RANKL complex with Kd value of $549.38 \mathrm{nM}$ and with estimated free energy of binding $-8.54 \mathrm{kcal} / \mathrm{mol}$. Gambogic acid is found to be significant drug template for target specific osteosarcoma treatment.
\end{abstract}

Keywords: Osteosarcoma, Saos-2, Gambogic acid, RANK, RANKL, OPG

\section{Osteosarkom Hücre Hattında Hedefe Spesifik RANKL İnhibitörü Olarak Gambojik Asidin Antikanser Profili}

Öz

Osteosarkom, genç nüfus arasında yaygın bir kanser türüdür ve genellikle büyüyen kemiklerde gelişir. Osteosarkom vakalarının yaklaşık yüzde yirmisi metastaz eğilimi gösterir ve osteosarkomlu hastaların tedaviden sonra hayatta kalma oranı düşüktür. Kemiğin yeniden şekillenmesinin RANK / RANKL / OPG anahtar düzenleyici üçlüsü, osteosarkomun tümör oluşumunda kritik rol oynar. Gambojik asidin anti-proliferatif aktivitesi, XTT testi ile Saos-2 hücre hattında belirlendi. Gambojik asidin antikanser aktivitelerini anlamak için RANK-RANKL kompleksi ile moleküler docking hesaplamaları da yapıldı. RANKL ve OPG'nin ekspresyon seviyeleri, RT-PCR ve ELISA deneyleri ile gen ve protein seviyesinde ölçüldü. Osteosarkom hücrelerine karş1 in vitro potansiyel anti-invazif özelliği, yara iyileştirme deneyi kullanılarak değerlendirildi. Deneysel analizler, gambojik asidin Saos-2 hücrelerinde hücre proliferasyonunu, hücre göçünü ve RANKL / OPG'nin protein ekspresyon oranını azalttığını gösterdi. Gambogic asit, 549.38 nM'lik Kd değeri ve -8.54 kcal / mol'lük tahmini serbest enerji ile RANK-RANKL kompleksine bağlandı. Gambojik asidin, hedefe özgü osteosarkom tedavisi için önemli ilaç şablonu olduğu bulunmuştur.

Anahtar Kelimeler: Osteosarkom, Saos-2, Gambojik asit, RANK, RANKL, OPG

\section{Introduction}

Osteosarcoma (osteogenic sarcoma) is the most common bone cancer subtype in the world. Osteosarcoma is predominantly diagnosed in adolescents and young adults. Approximately 3\% of childhood cancer cases are osteosarcoma in United States (Misaghi et al., 2018; Ottaviani and Jaffe, 2009). Tumors occur predominantly in the long bones (distal femur and proximal tibia) and osteosarcoma can arise in soft tissues outside of the bones especially in older patients. 
Age, gender, radiation, genetic disorders (retinoblastoma and Li-Fraumeni syndrome) and bone infarct are important risk factors to develop osteosarcoma, but their molecular interactions with osteosarcoma have not been fully understood yet (Hameed and Mandelker, 2018; Huang et al., 2018). About 1 out of 5 osteosarcomas tends to spread mostly over lungs and it can also spread to brain, other bones and organs. Especially, survival rates decreases from $60-70 \%$ to $20-30 \%$ in metastatic osteosarcoma cases (Huang et al., 2019; Shweikeh et al., 2014). Chemotherapy is an important part of treatment of osteosarcoma, and cisplatin, doxorubicin, dactinomycin, methotrexate, cyclophosphamide and denosumab are extensively used in prevention of osteosarcoma and its metastases (Wang et al., 2017). Notedly, we need target specific and more effective therapeutics to increase the success of treatment in patients with non-metastatic and metastatic osteosarcoma.

RANK/RANKL/OPG is a key signaling pathway which involves in modeling and re-modeling of bones, development of mammary gland, adaptive immunity and especially survival and migration of breast, prostate and bone cancer cells. RANK/RANKL/OPG pathway is also closely associated with the tumorigenesis of osteosarcoma. RANKL (receptor activator of nuclear factor- $\kappa \mathrm{B}$ ligand, also known as TNFSF11, OPGL, ODF, and TRANCE) is produced by osteoblasts and stromal stem cells, and play significant roles as an inducer of osteoclastogenesis. RANKL binds to RANK (receptor activator of nuclear factor- $\kappa \mathrm{B}$, also known as TNFRSF11A) and promotes both maturation osteoclasts from precursors and activation of mature osteoclasts. OPG (osteoprotegerin, also known as TNFRSF11B) is expressed by osteoblasts and bone marrow stromal cells and it is defined as decoy receptor for RANKL to prevent interaction between RANKL and RANK. Thus, OPG inhibits osteoclastogenesis and induces apoptosis in bone cancer cells (Baud'huin et al., 2007; Boyce and Xing, 2009; Ono et al., 2020; Boyce and Xing, 2007). Therefore, expression ratio of RANKL/OPG could be important biomarker for bone homeostasis.

RANK and RANKL are over-expressed in osteosarcoma cells and aberrant expression of these proteins is poor prognostic marker as demonstrated in osteosarcoma. Higher RANK and RANKL productions in the osteosarcoma tumors are strongly associated with cell proliferation, metastases and drug resistance pathways in osteosarcoma. Furthermore, increased RANKL/OPG ratio in patients with osteosarcoma supports survival and activation of tumourigenesis. Therefore, RANKL inhibition has been significant approach to design target specific drugs in treatment of osteosarcoma. In pre-clinical and clinical models, RANKL inhibition has been shown to disrupt bone resorption by suppressing osteoclastogenesis and prevent tumourigenesis in osteosarcoma (Ando et al., 2008; Branstetter et al., 2015; Trinidad and Gonzalez-Suarez, 2016). To improve survival rates with chemotherapy in osteosarcoma, patients need more selective and effective RANKL inhibitors.

Gambogic acid is a xanthonoid derivative natural compound which is isolated from Garcinia hanburyi tree (Figure 1). Gambogic acid has been used in traditional medicine to treat various diseases for centuries. Interest in gambogic acid as an anticancer drug candidate has increased in recent years due to its anti-proliferative, anti-metastatic and apoptotic potentials against a wide variety of cancer types. To treat advanced malignant tumors, gambogic acid has been approved by the China Food and Drug Administration (CFDA) for phase-II clinical studies (Wen et al., 2015; Wang and Chen, 2012; Chi et al., 2013). Several experimental studies reported that gambogic acid stimulates the accumulation of reactive oxygen species (ROS) in cancer cells contributing to its anti-cancer activity. Thus, gambogic acid interrupts cellular 
redox homeostasis and increases oxidative stress in cancer cells, leading to apoptotic and autophagic cell death (Ishaq et al., 2014; Wang et al., 2019; Nie et al., 2009). Also, treatment with gambogic acid significantly inhibits invasion and migration in cancer cells (Zhou and ma, 2019; Kashyap et al., 2016). However, molecular mechanism of anti-cancer activity of gambogic acid has largely unknown yet.

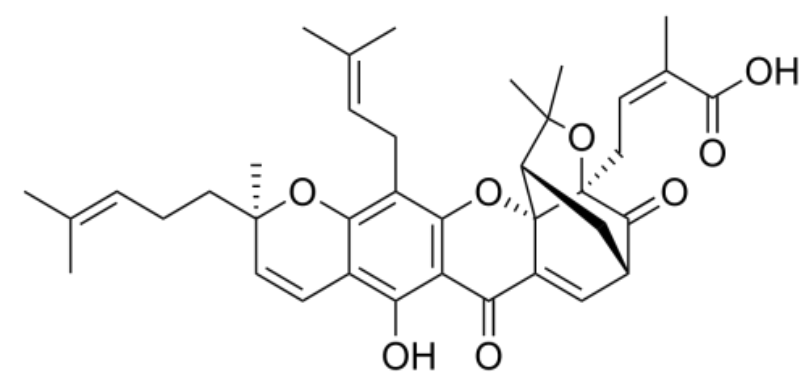

Figure 1. Chemical structure of gambogic acid

The current study evaluated the anti-proliferative and anti-metastatic effects of gambogic acid and the underlying molecular mechanisms in human osteosarcoma cell line. Obtained results demonstrated that gambogic acid inhibited RANKL activity and suppressed proliferation and invasion of human osteosarcoma cells.

\section{Materials and Methods}

\subsection{Materials}

Saos-2 cell line (ATCC ${ }^{\circledR}$ HTB-85 ${ }^{\mathrm{TM}}$ ) was obtained from ATCC (American Type Culture Collection, USA). Modified McCoy's 5A medium, trypsin-EDTA, phosphate buffer saline (PBS), heat-inactivated fetal bovine serum (FBS), gentamycin, L-glutamine and XTT (2,3-bis(2-methoxy-4-nitro-5-sulfophenyl)-2H-tetrazolium-5-carboxanilide) cell proliferation kit were purchased from Biological Industries Ltd. Gambogic acid was from Abcam. Total RNA isolation and cDNA synthesis kits were from Bioline. SYBR Green master mix was obtained from Qiagen. Primers were synthesized from Macrogen. Total oxidant status (TOS) and Total antioxidant status (TAS) kits were supplied from Rel Assay Diagnostics (Turkey). All other chemical reagents were supplied from Merck and Sigma Aldrich.

\subsection{Cell culture and treatment}

Saos-2 cell line was cultured in modified McCoy's 5A medium supplemented with $10 \%$ fetal bovine serum and $0.1 \%$ gentamycin. Cells were maintained in $5 \% \mathrm{CO}_{2}$ at a temperature of $37^{\circ} \mathrm{C}$. Gambogic acid was dissolved in dimethyl sulfoxide (DMSO) at a concentration of 200 $\mathrm{mM}$ and stored at $4^{\circ} \mathrm{C}$ as a stock solution. The stock solution was diluted with modified McCoy's 5A medium and Saos-2 cells were exposed to gambogic acid in wide concentration range $(12.5 \mu \mathrm{M}-0.2 \mu \mathrm{M})$ for $48 \mathrm{~h}$. Cells grown in media containing equivalent amount of DMSO without gambogic acid served as control.

\subsection{Cell proliferation assay}

The effects of gambogic acid on the viability of Saos-2 cells were evaluated using the XTT cell proliferation assay, according to optimized protocol (Koca et al., 2015; Gümüs et al., 2016). The cells were plated in 96-well cell culture plate ( $1 \times 10^{5}$ cells in each well) and after overnight incubation the cells were treated with different concentrations of gambogic acid for $48 \mathrm{~h}$. After treatment, medium and gambogic acid were carefully removed by aspiration and the cells were 
washed with PBS three times. Then, $50 \mu \mathrm{l}$ of XTT reagents were added to each well and microplate reader was used to measure the absorbance at $450 \mathrm{~nm}$. The cell viability was determined in percentage compared to control and the $\mathrm{IC}_{50}$ value of gambogic acid was assessed with GraphPad Prism software. All experiments were performed for three independent times.

\subsection{Molecular docking calculations}

To evaluate the anticancer mechanism of gambogic acid action in osteosarcoma cells, molecular docking calculations were performed in the interaction surface of the RANK-RANKL protein complex (pdb code: 3ME2). Docking calculations were carried out using the Docking Server (http://www.dockingserver.com/web) web tool. 2D-structure of gambogic acid was extracted from DrugBank Databases; hydrogen atoms were added and saved as pdb format. The grid box size of RANK-RANKL was set to $45 x 47 x 60$ xyz points. PyMOL software was used to visualize and analyze the molecular docking results.

\subsection{Measurement of RANKL and OPG protein levels}

To determine protein expression level of RANKL and OPG in gambogic acid-treated and untreated Saos-2 cells, sandwich ELISA kits were used according to the manufacturers' instructions. At the end of the incubation time, gambogic acid-treated Saos- 2 cells were washed with PBS and ice-cold lysis buffer (50 mM Tris-HCl, $150 \mathrm{mM} \mathrm{NaCl}, 1 \%$ Triton X-100, $0.2 \mathrm{mM}$ PMSF, pH:7.4) was applied and incubated during 15 min on ice. Then, the cells were scraped with sterile cell scrapers and cell lysate was passed thought sterile 21 gauge needle attached on a $5 \mathrm{ml}$ syringe. After centrifugation process, pellet was discarded and cell lysate stored at -80 ${ }^{\circ} \mathrm{C}$ to perform ELISA assays.

\subsection{RT-PCR analysis}

To investigate the alteration of RANKL and OPG gene expressions in effect of gambogic acid, RT-PCR experiments were carried out on Saos-2 cells. Same experiment without gambogic acid used as negative control and all experiments were performed twice. Saos-2 cells were incubated with $48 \mathrm{~h} \mathrm{IC}_{50}$ value of the gambogic acid. At the end of the incubation time, total RNA was isolated and cDNA was synthesized with purchased commercial kits. Human RANKL (forward: 5'-GCCAGTGGGAGATGTTAG-3' and reverse: 5'TTAGCTGCAAGTTTTCCC-3'), OPG (forward: 5'-GAACCCCAGAGCGAAATACA-3' and reverse: 5'-TATTCGCCACAAACTGAGCA-3') and $\beta$-actin (forward: 5'CTCCATCCTGGCCTCGCTGT-3' and reverse: 5'-GCTGTCACCTTCACCGTTCC-3') primers were used in this experiment (Peng et al., 2013). RT-PCR experiments were performed in Roche LightCycler ${ }^{\circledR} 480$ RT-PCR system using a SYBR Green master mix. The standard RT-PCR condition was $95{ }^{\circ} \mathrm{C}$ for $10 \mathrm{~min}$, followed by 40 cycles of $95{ }^{\circ} \mathrm{C}$ (10 seconds), $58{ }^{\circ} \mathrm{C}$ (10 seconds) and an extension step, $72{ }^{\circ} \mathrm{C}$ (15 seconds). Analyses were repeated three times and relative expression of target genes was determined using the $2^{-\Delta \Delta \mathrm{Ct}}$ method.

\subsection{Cell migration assay}

This assay was performed to determine anti-invasive activity of gambogic acid in osteosarcoma cells. Saos- 2 cells were plated in 6 -well cell culture plate ( $2 \times 10^{5}$ cells in each well) and the cells were incubated until they reached approximately $90 \%$ cell confluence. To create a scratch line, the cell monolayers were scraped with sterile p200 yellow pipet tip and then the cells were washed with PBS to remove debris and smooth the edges of the lines. Gambogic acid $(0.1 \mu \mathrm{M})$ was treated with scratched cells for $48 \mathrm{~h}$. Then, the closure of starches was photographed and 
migration analyses were performed with Olympus CKX53 inverted microscope. The closure of the $0 \mathrm{~h}$ wound area was assumed $100 \%$ and the migration levels of the gambogic acid and control were calculated proportionally with starting wound area.

\subsection{Statistical analysis}

Statistical analysis and comparable data groups were assessed using GraphPad Prism 6.0 software by one-way ANOVA test. Probability values of $\mathrm{p}<0.05$ were considered to be statistically significant.

\section{Results}

Therapeutic potentials of natural compounds have been extensively evaluated against various diseases for a long time. Gambogic acid is an important member of the herbal medicine and exhibits anti-proliferative activity against in a wide variety of cancer types in experimental studies (Liu et al., 2020; Xu et al., 2012). In the present study, anti-proliferative and antimetastatic activities of gambogic acid were investigated in Saos-2 cell line by in-silico and invitro studies.

\subsection{Effects of gambogic acid on human Saos-2 cells proliferation}

To investigate the effects of gambogic acid on human osteosarcoma cell proliferation, Saos-2 cells were treated with gambogic acid for $48 \mathrm{~h}$. IC 50 value of gambogic acid was calculated as $0.88 \mu \mathrm{M}$ at $48 \mathrm{~h}$ and the percentage of cell survival was visualized in Figure 2.

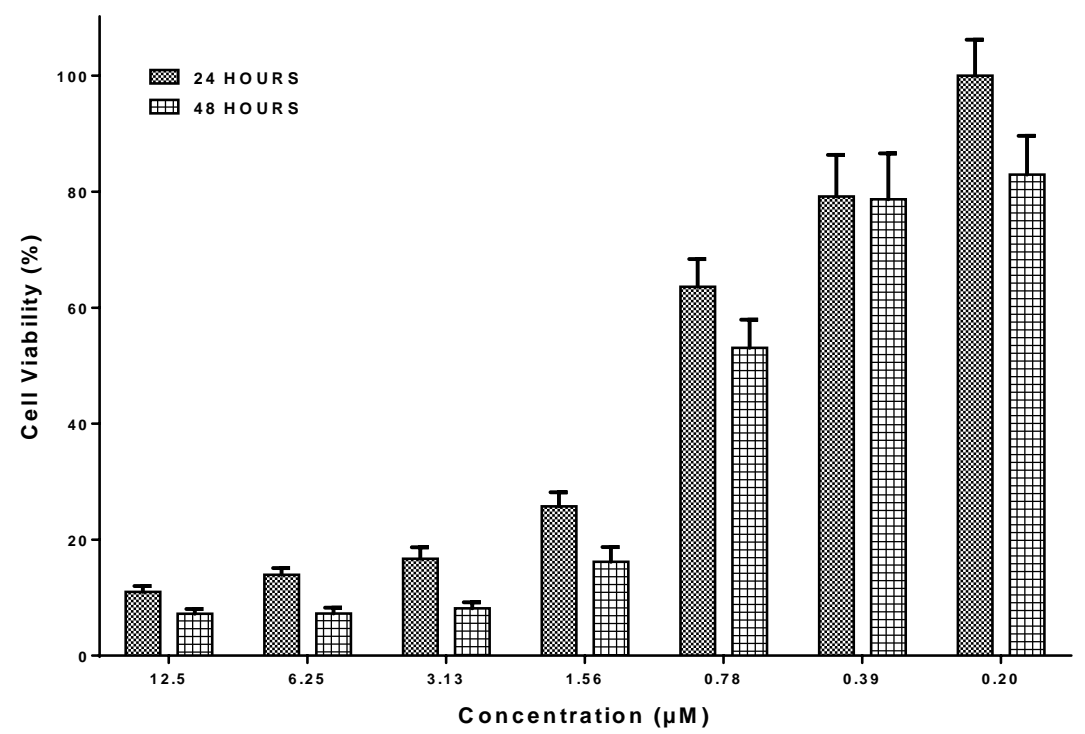

Figure 2. Anticancer activity of gambogic acid as percent cell viability after $24 \mathrm{~h}$ and $48 \mathrm{~h}$ in Saos-2 cell line at different concentrations.

XTT assay results indicated that gambogic acid exhibited significant cytotoxic effect against Saos-2 cells in a time and dose-dependent manner. Also, $\mathrm{IC}_{50}$ value of gambogic acid was calculated as $0.88 \mu \mathrm{M}$ at $48 \mathrm{~h}$ in Saos- 2 cells. Previous studies revealed that gambogic acid exhibited significant toxicity on various cancer types and its $\mathrm{IC}_{50}$ values is around low $\mu \mathrm{M}$ levels in cancer cells (Liu et al., 2020; Xu et al., 2012). The molecular mechanisms of the anticancer activities of gambogic acid could be determined with further biochemical experiments in Saos-2 cells.

\subsection{Molecular docking studies}

To support in vitro experiments on the interaction between gambogic acid and RANK-RANKL complex, molecular docking calculation was employed. The free energy of binding and 
inhibition constant of the gambogic acid were calculated and Figure 3 exhibits specific interactions of gambogic acid with RANK-RANKL complex. Gambogic acid was selectively interacted with RANK-RANKL interface region and its estimated binding energy and inhibition constant were calculated as $-8.54 \mathrm{kcal} / \mathrm{mol}$ and $549.38 \mathrm{nM}$ respectively (Figure 3). RANKRANKL protein complex contains ligand binding site and cavity. In ligand binding region of the RANK-RANKL complex, Phe280 and Met255 make hydrophobic pocket (red color in Figure 3) to interact with compounds.

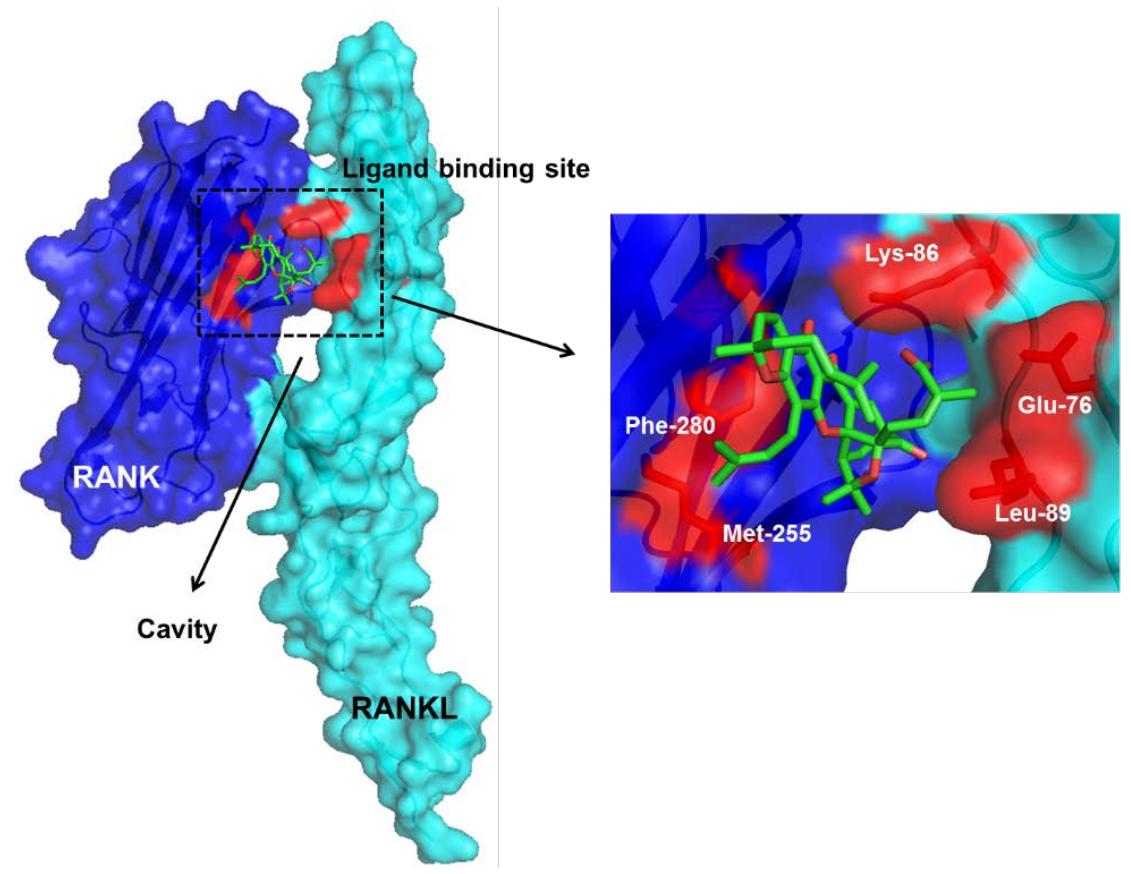

Figure 3. Interactions of gambogic acid (shown in green) with RANK-RANKL complex (RANK is blue, RANKL is cyan, key residues (Glu76, Lys86, Leu89, Met255 and Phe280) are red).

Molecular docking calculation results indicated that gambogic acid was selectively interacted with RANK-RANKL protein complex. As shown in Figure 3, gambogic acid binds ligand binding region of the RANK-RANKL. Moreover, gambogic acid is formed binding pocket with residues including Glu76, Lys86, Leu89, Met255 and Phe280. Interaction of gambogic acid with these residues leads to conformational changes of the protein complex and perturb RANKRANKL activity. Thus, tumorigenesis of osteosarcoma and associated signaling pathways are interrupted to perform oncogenic mechanisms.

Molecular docking calculation results indicated that gambogic acid was selectively interacted with RANK-RANKL protein complex. As shown in Figure 3, gambogic acid binds ligand binding region of the RANK-RANKL. Moreover, gambogic acid is formed binding pocket with residues including Glu76, Lys86, Leu89, Met255 and Phe280. Interaction of gambogic acid with these residues leads to conformational changes of the protein complex and perturb RANKRANKL activity. Thus, tumorigenesis of osteosarcoma and associated signaling pathways are interrupted to perform oncogenic mechanisms.

\section{3. mRNA and protein levels of RANKL and OPG}

To elucidate osteosarcoma signalling pathway affected by gambogic acid in Saos-2 cells, RTPCR and ELISA experiments was carried out to determine the mRNA and protein expressions of RANK and OPG. As shown in Figure 4, the RANKL gene expression did not significantly 
change compared to control in Saos-2 cells. However, the expression of OPG gene was also dramatically up-regulated by gambogic acid treatment in osteosarcoma cells. ELISA results demonstrated that, gambogic acid decreased protein amount of RANK and RANKL, and it increased OPG level compare to control in Saos-2 cells.
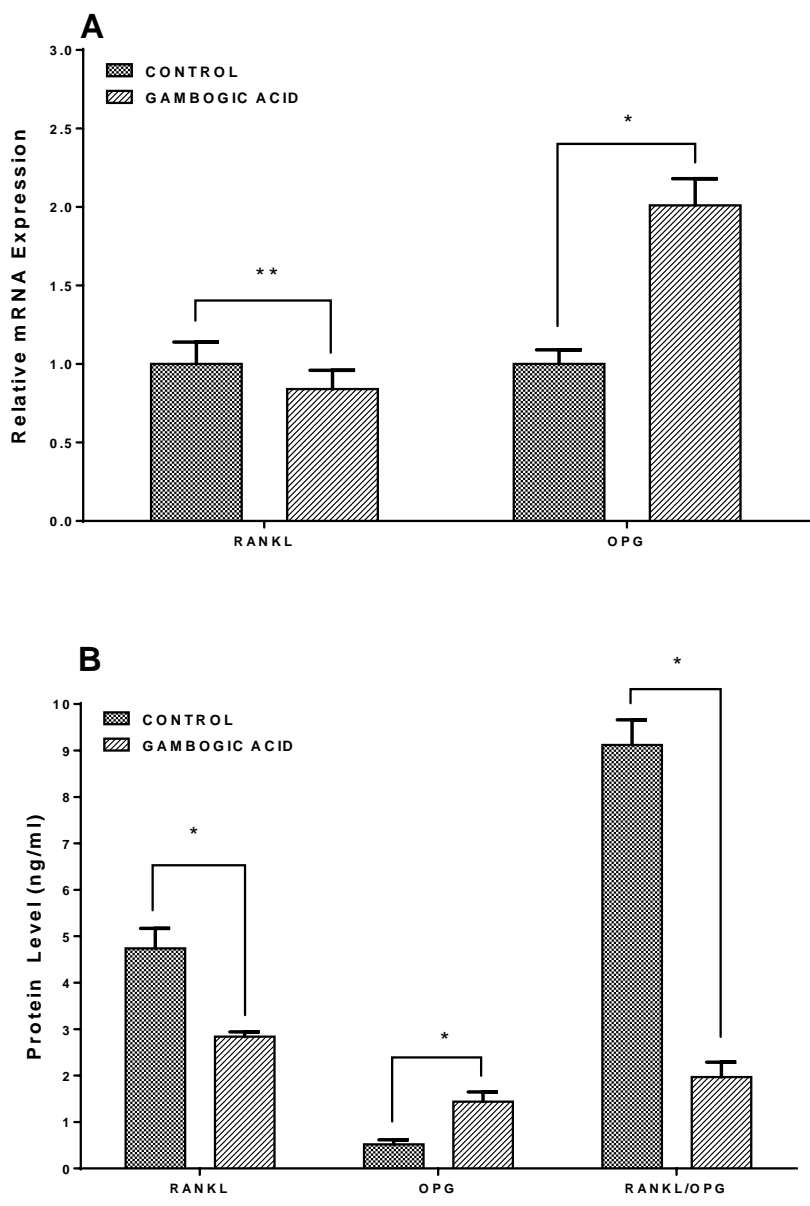

Figure 4. A) Relative mRNA expression levels of RANKL and OPG detected by RT-PCR (* $\left.\mathrm{p}<0.01,{ }^{* *} \mathrm{p}<0.05\right)$ B) Protein levels of RANKL and OPG $(* \mathrm{p}<0.01)$

The data suggest that gambogic acid directly represses RANKL expression at protein level and the mRNA expression level of OPG is correlated with its protein level. Moreover, RANKL/OPG ratio was decreased from 9.75 to 4.72 with gambogic acid. Decreased RANKL/OPG ratio supports anti-proliferative and anti-invasive properties of the gambogic acid in this study. Briefly, gambogic acid is promising candidate as target specific RANKL inhibitor in treatment of osteosarcoma. RANK/RANKL/OPG signaling pathway plays significant roles in tumorigenesis of osteosarcoma. Aberrant expression of RANKL and upregulation of RANKL/OPG ratio leads formation of osteosarcoma. Further, increased RANKL level stimulates formation of osteosarcoma and its metastases pathways. On the contrary, upregulation of the OPG level inhibits not only osteosarcoma-induced osteolysis but also tumor development (Ando et al., 2008). Therefore, down-regulation of RANKL and up-regulation of OPG are desired molecular outcomes from target specific osteosarcoma therapeutics. 


\subsection{Cell migration assay}

A wound healing experiment was performed in order to investigate the effect of gambogic acid on Saos- 2 cell migration. The results in Figure 5 demonstrated that osteosarcoma cell migration was inhibited by $0.1 \mu \mathrm{M}$ of gambogic acid compared with control group. The wound area of control and gambogic acid treated Saos-2 cells were calculated as approximately $72 \%$ and $78 \%$ respectively after $24 \mathrm{~h}$. At the end of the $48 \mathrm{~h}$, the wound areas were determined about $9 \%$ and $65 \%$ in control and gambogic acid treated osteosarcoma cells respectively (Figure-4).
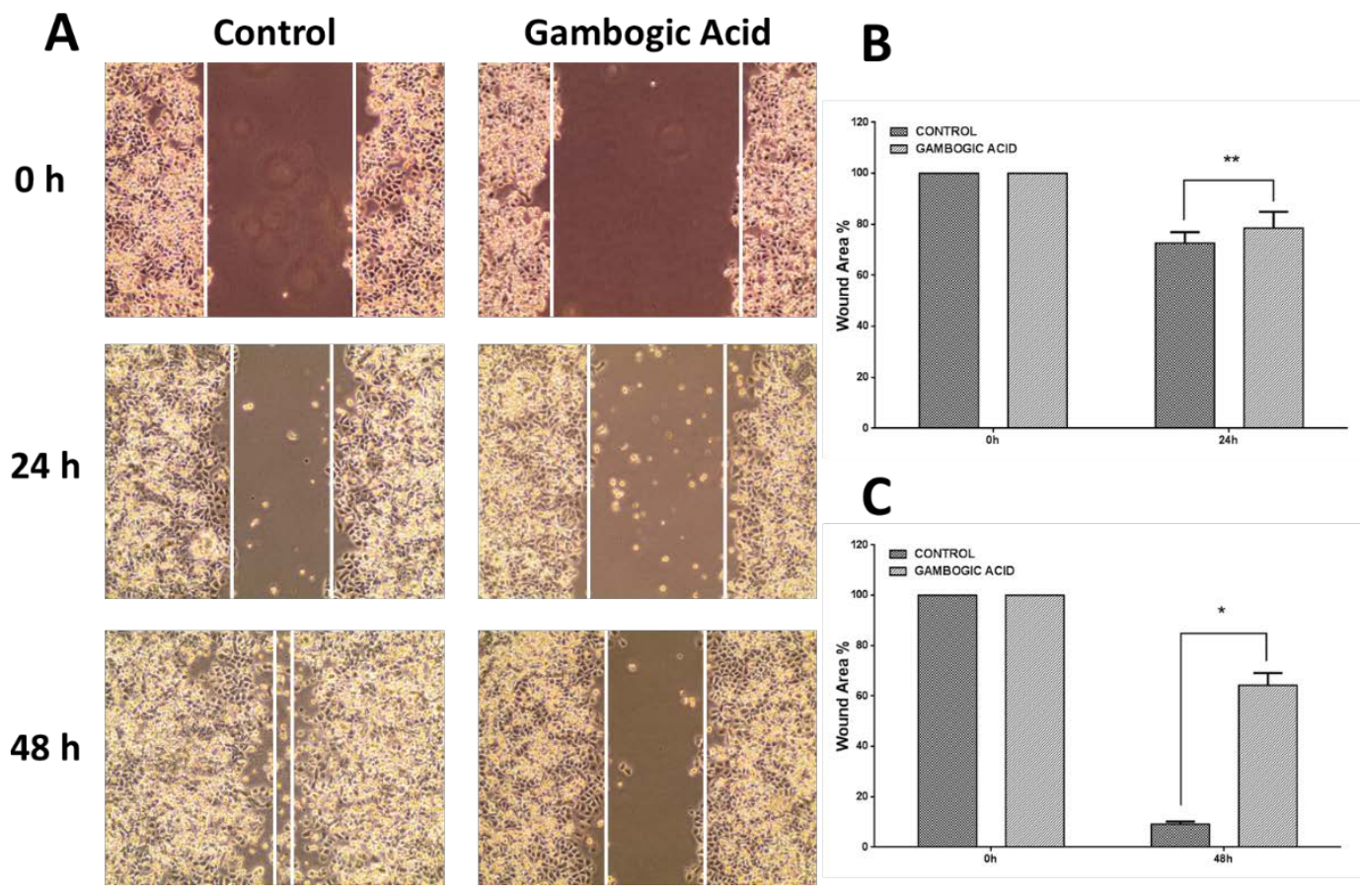

Figure-5. A) Scratch-wounding cell migration assay results of gambogic acid and control in Saos-2 cells (C: Control, G: gambogic acid) B) Bar graph illustrating percentage wound closure at $24 \mathrm{~h}$ during the wound healing assay $\left({ }^{*} \mathrm{p}<0.01\right)$. C) Bar graph illustrating percentage wound closure at $48 \mathrm{~h}$ during the wound healing assay $(* * \mathrm{p}<0.05)$.

Invasive capacity of the cancer cells into surrounding tissues is the most important parameter in tumor metastases. Approximately 25-30 percent patients with osteosarcoma have metastases especially to the lung and other bones. The prognosis for patients with metastatic osteosarcoma and five-year survival rate for osteosarcoma is extremely low level. Therefore, designing of anti-proliferative and anti-metastatic therapeutic agents are important approach for targeted osteosarcoma treatment. Thus, gambogic acid has the potential to prevent both cell proliferation and metastasis in osteosarcoma. In the literature, anti-invasive properties of gambogic acid are reported in cancer cells. Importantly, matrix metalloproteinase-1 (TIMP-1) is responsible for activation of MMPs-mediated metastasis. Gambogic acid exhibits the inhibitory effects on TIMP-1 in osteosarcoma cells (Xin et al., 2013). Cell adhesion molecules such as integrins, have a vital roles in the invasion process (Ganguly et al., 2013). Gambogic acid inhibits $\beta$ integrin expression and the role of lipid rafts in the regulation of $\beta$-integrin in lung cancer cells. Furthermore, integrin $\beta 1$ /rho family GTPase downstream signaling molecules (MMP-2, MMP9 , and NF- $\kappa \beta$ ) play significant roles in cellular invasion processes and they are inhibited in GAtreated liver adenocarcinoma cell line (SK-HEP1) (Kashyap et al., 2016). Gambogic acid may be employed in combinatory therapy and designing treatment regimens of additive drug pairs decrease cancer cell invasion of the individual compound as well as proliferation. 


\section{Conclusion}

Increasing of RANKL/OPG ratio is considered to reduced osteoclast formation and bone resorption in osteosarcoma. In current study, anticancer activity of gambogic acid was determined in human osteosarcoma cell line. Experimental assays demonstrated that, gambogic acid decreased protein expression ratio of RANKL/OPG and inhibited Saos-2 cell proliferation and invasion in a dose-dependent manner. Gambogic acid was selectively bond with ligand binding site of the RANK-RANKL complex and chimeric structures of gambogic acid provided efficient inhibition for interaction of RANK and RANKL. Furthermore, gambogic acid decreased oxidative stress level in osteosarcoma cells. In this regard, gambogic acid is potent new therapeutic agents for osteosarcoma. Therefore, gambogic acid and its templates are promising drug candidates due to the product complexity and molecule potency.

\section{Acknowledgment}

This work was supported by Research Fund of the Tokat Gaziosmanpaşa University. Project number: 2019/86.

\section{Conflict of Interest}

The authors confirm that this article content has no conflicts of interest.

\section{References}

Ando, K., Mori, K., Rédini, F., Heymann, D. (2008). RANKL/RANK/OPG: key therapeutic target in bone oncology. Current Drug Discovery Technologies,5, 263-268.

Baud'huin, M., Duplomb, L., Ruiz Velasco, C., Fortun, Y., Heymann, D., Padrines, M. (2007). Key roles of the OPG-RANK-RANKL system in bone oncology. Expert Review of Anticancer Therapy, 7, 221-232.

Boyce, B.F., Xing, L. (2007). The RANKL/RANK/OPG pathway. Current Osteoporosis Reports, 5, 98-104.

Boyce, B.F., Xing, L. (2009). Functions of RANKL/RANK/OPG in bone modeling and remodeling. Archives of Biochemistry and Biophysics, 473, 139-146.

Branstetter, D., Rohrbach, K., Huang, L.Y., Soriano, R., Tometsko, M., Blake, M., Jacob, A.P., Dougall, W.C. (2015). RANK and RANK ligand expression in primary human osteosarcoma. Journal of Bone Oncology, 4, 59-68.

Chi, Y., Zhan, X.K., Yu, H., Xie, G.R., Wang, Z.Z., Xiao, W., Wang, Y.G., Xiong, F.X., Hu, J.F., Yang, L., Cui, C.X., Wang, J.W. (2013). An open-labeled, randomized, multicenter phase IIa study of gambogic acid injection for advanced malignant tumors. Chinese Medical Journal, 126, 1642-1646.

Ganguly, K.K., Pal, S., Moulik, S., Chatterjee, A. (2013). Integrins and metastasis. Cell Adhesion \& Migration, 7, 251-261. 
Gümus, M., Ozgur, A., Tutar, L., Disli, A., Koca, I., Tutar, Y. (2016). Design, Synthesis, and Evaluation of Heat Shock Protein 90 Inhibitors in Human Breast Cancer and Its Metastasis. Current Pharmaceutical Biotechnology, 17, 1231-1245.

Hameed, M., Mandelker, D. (2018). Tumor Syndromes Predisposing to Osteosarcoma. Advances in Anatomic Pathology, 25, 217-222.

Huang X, Zhao J, Bai J, Shen H, Zhang B, Deng L, Sun, C., Liu, Y., Zhang, J., Zheng, J. (2019). Risk and clinicopathological features of osteosarcoma metastasis to the lung: A populationbased study. Journal of Bone Oncology,16, 100230.

Huang, J., Bi, W., Han, G., Jia, J., Xu, M., Wang, W. (2018). The multidisciplinary treatment of osteosarcoma of the proximal tibia: a retrospective study. BMC Musculoskeletal Disorders,19, 315.

Ishaq, M., Khan, M.A., Sharma, K., Sharma, G., Dutta, R.K., Majumdar, S. (2014). Gambogic acid induced oxidative stress dependent caspase activation regulates both apoptosis and autophagy by targeting various key molecules (NF-kB, Beclin-1, p62 and NBR1) in human bladder cancer cells. Biochimica et Biophysica Acta, 1840, 3374-3384.

Kashyap, D., Mondal, R., Tuli, H.S., Kumar, G., Sharma, A.K. (2016). Molecular targets of gambogic acid in cancer: recent trends and advancements. Tumor Biology, 37, 12915-12925.

Koca, İ., Gümüş, M., Özgür, A., Dişli, A., Tutar, Y. (2015). A Novel Approach to Inhibit Heat Shock Response as Anticancer Strategy by Coumarine Compounds Containing Thiazole Skeleton. Anti-Cancer Agents in Medicinal Chemistry, 15, 916-930.

Liu, Y., Chen, Y., Lin, L., Li, H. (2020). Gambogic Acid as a Candidate for Cancer Therapy: A Review. International Journal of Nanomedicine, 15, 10385-10399.

Misaghi, A., Goldin, A., Awad, M., Kulidjian, A.A. (2018). Osteosarcoma: a comprehensive review. SICOT J, 4, 12.

Nie, F., Zhang, X., Qi, Q., Yang, L., Yang, Y., Liu, W., Lu, N., Wu, Z., You, Q., Guo, Q. (2009). Reactive oxygen species accumulation contributes to gambogic acid-induced apoptosis in human hepatoma SMMC-7721 cells. Toxicology, 260, 60-67.

Ono, T., Hayashi, M., Sasaki, F., Nakashima, T. (2020). RANKL biology: bone metabolism, the immune system, and beyond. Inflammation and Regeneration, 40, 2.

Ottaviani, G., Jaffe, N. (2009). The epidemiology of osteosarcoma. Cancer Treatment and Research, 152, 3-13.

Peng, X., Guo, W., Ren, T., Lou, Z., Lu, X., Zhang, S., Lu, Q., Sun, Y. (2013). Differential expression of the RANKL/RANK/OPG system is associated with bone metastasis in human non-small cell lung cancer. PLoS One, 8: e58361. 
Shweikeh F, Bukavina L, Saeed K, Sarkis R, Suneja A, Sweiss F, Drazin, D. (2014). Brain Metastasis in Bone and Soft Tissue Cancers: A Review of Incidence, Interventions, and Outcomes. Sarcoma, 2014, 475175.

Trinidad, E.M,, González-Suárez, E. (2016). RANKL inhibitors for osteosarcoma treatment: hope and caution. Annals of Translational Medicine, 4, 534.

Wang, H., Zhao, Z., Lei, S., Li, S., Xiang, Z., Wang, X., Huang, X., Xia, G., Huang, X. (2019). Gambogic acid induces autophagy and combines synergistically with chloroquine to suppress pancreatic cancer by increasing the accumulation of reactive oxygen species. Cancer Cell International,19, 7.

Wang, X., Chen, W. (2012). Gambogic acid is a novel anti-cancer agent that inhibits cell proliferation, angiogenesis and metastasis. Anti-Cancer Agents in Medicinal Chemistry,12, 994-1000.

Wang, X., Zheng, H., Shou, T., Tang, C., Miao, K., Wang, P. (2017). Effectiveness of multidrug regimen chemotherapy treatment in osteosarcoma patients: a network meta-analysis of randomized controlled trials. Journal of Orthopaedic Surgery and Research,12, 52.

Wen, C., Huang, L., Chen, J., Lin, M., Li, W., Lu, B., Rutnam, Z.J., Iwamoto, A., Wang, Z., Yang, X., Liu, H. (2015) Gambogic acid inhibits growth, induces apoptosis, and overcomes drug resistance in human colorectal cancer cells. International Journal of Oncology,47, 16631671.

Xin, Z.F., Shen, C.C., Tao, L.J., Yan, S.G., Wu, H.B. (2013). Gambogic acid inhibits invasion of osteosarcoma via upregulation of TIMP-1. International Journal of Molecular Medicine, 31, 105-112.

Xu, B., Ding, J., Chen, K.X., Miao, Z.H., Huang, H., Liu, H., Luo, X.M. (2012). Advances in Cancer Chemotherapeutic Drug Research in China. Recent Advances in Cancer Research and Therapy, 287-350.

Zhou, Z., Ma, J. (2019). Gambogic acid suppresses colon cancer cell activity in vitro. Experimental and Therapeutic Medicine, 18, 2917-2923. 